\title{
Sulfation of Condensed Potassium Chloride by SO2
}

Sengeløv, Louise With; Hansen, Troels Bruun; Bartolome, Carmen; Wu, Hao; Pedersen, Kim H.; Jappe Frandsen, Flemming; Jensen, Anker Degn; Glarborg, Peter

\section{Published in:}

The Open Fuels \& Energy Science Journal

Link to article, DOI:

$10.1021 /$ ef400405z

Publication date:

2013

Document Version

Publisher's PDF, also known as Version of record

Link back to DTU Orbit

Citation (APA):

Sengeløv, L. W., Hansen, T. B., Bartolome, C., Wu, H., Pedersen, K. H., Jappe Frandsen, F., Jensen, A. D., \& Glarborg, P. (2013). Sulfation of Condensed Potassium Chloride by SO2. The Open Fuels \& Energy Science Journal, 27(6), 3283-3289. https://doi.org/10.1021/ef400405z

\section{General rights}

Copyright and moral rights for the publications made accessible in the public portal are retained by the authors and/or other copyright owners and it is a condition of accessing publications that users recognise and abide by the legal requirements associated with these rights.

- Users may download and print one copy of any publication from the public portal for the purpose of private study or research.

- You may not further distribute the material or use it for any profit-making activity or commercial gain

- You may freely distribute the URL identifying the publication in the public portal 


\title{
Sulfation of Condensed Potassium Chloride by $\mathrm{SO}_{2}$
}

\author{
Louise With Sengeløv, ${ }^{\dagger}$ Troels Bruun Hansen, ${ }^{\dagger}$ Carmen Bartolomé, ${ }^{\dagger}$ Hao Wu, ${ }^{\dagger}$ Kim H. Pedersen, ${ }^{\S}$ \\ Flemming J. Frandsen, ${ }^{\dagger}$ Anker D. Jensen, ${ }^{\dagger}$ and Peter Glarborg ${ }^{*}, \dagger$ \\ ${ }^{\dagger}$ Department of Chemical and Biochemical Engineering, Technical University of Denmark, DK-2800 Kgs. Lyngby, Denmark \\ ${ }^{\ddagger}$ CIRCE (Centre of Research for Energy Resources and Consumption), University of Zaragoza, C/Mariano Esquillor Gómez, 15, \\ 50018 Zaragoza, Spain \\ ${ }^{\S}$ FLSmidth A/S, Vigerslev Allé 77, DK-2500 Valby, Denmark
}

ABSTRACT: The interaction between alkali chloride and sulfur oxides has important implications for deposition and corrosion in combustion of biomass. In the present study, the sulfation of particulate $\mathrm{KCl}(90-125 \mu \mathrm{m})$ by $\mathrm{SO}_{2}$ was studied in a fixed bed reactor in the temperature range $673-1023 \mathrm{~K}$ and with reactant concentrations of $500-3000 \mathrm{ppm} \mathrm{SO}_{2}, 1-20 \% \mathrm{O}_{2}$, and 4-15\% $\mathrm{H}_{2} \mathrm{O}$. The degree of sulfation was monitored by measuring the formation of $\mathrm{HCl}$. Analysis of the solid residue confirmed that the reaction proceeds according to a shrinking core model and showed the formation of an eutectic at higher temperatures. On the basis of the experimental results, a rate expression for the sulfation reaction was derived. The model compared well with literature data for sulfation of $\mathrm{KCl}$ and $\mathrm{NaCl}$, and the results indicate that it may be applied at even higher $\mathrm{SO}_{2}$ concentrations and temperatures than those of the present study. Simulations of sulfation of $\mathrm{KCl}$ particles with different size indicate that only for very small $\mathrm{KCl}$ particles, below $1 \mu \mathrm{m}$, a considerable in-flight sulfation is achievable at the short gas residence times typical of combustion systems.

\section{INTRODUCTION}

The sulfation of alkali chlorides has important implications for thermal conversion of biomass. During pyrolysis and combustion of biomass at temperatures above about $1073 \mathrm{~K}$, potassium is partly released to the gas-phase, ${ }^{1-12}$ typically as potassium chloride. For agricultural residues, the $\mathrm{KCl}$ release can be significant, $3,4,11,13$, 14 while woody biomass contains smaller quantities of $\mathrm{K}$ and $\mathrm{Cl}^{8,9,13-16}$ Once released, gaseous $\mathrm{KCl}$ may be sulfated by reaction with $\mathrm{SO}_{3}{ }^{17-22}$ or it may, during cooling, condense on particulates or heat transfer surfaces. ${ }^{18,23-26}$ If the particle loading in the system is low, $\mathrm{KCl}$ may form an aerosol by homogeneous nucleation. ${ }^{24,25,27}$

Potassium chloride has a number of adverse effects in combustion units. Once deposited on heat transfer surfaces, it may act to lower the melting temperature of the deposit, forming a sticky surface that promotes further deposition. ${ }^{26,28}$ Furthermore, its presence in the deposits may lead to severe corrosion by a mechanism where both potassium and chlorine are active in destroying the metal oxide protective layer. ${ }^{29}$ Another adverse effect of $\mathrm{KCl}$ is the ability to deactivate SCR catalysts; ${ }^{30-33}$ a phenomenon that limits the application of SCR for $\mathrm{NO}_{x}$ control in biomass fired systems.

The sulfation of condensed alkali chlorides proceeds as a gas-solid or gas-liquid reaction that may involve $\mathrm{SO}_{2}{ }^{34}$ or $\mathrm{SO}_{3}: 35$

$$
2 \mathrm{KCl}(\mathrm{s}, \mathrm{l})+\mathrm{SO}_{2}+\frac{1}{2} \mathrm{O}_{2}+\mathrm{H}_{2} \mathrm{O} \rightarrow \mathrm{K}_{2} \mathrm{SO}_{4}(\mathrm{~s}, \mathrm{l})+2 \mathrm{HCl}
$$

$$
2 \mathrm{KCl}(\mathrm{s}, \mathrm{l})+\mathrm{SO}_{3}+\mathrm{H}_{2} \mathrm{O} \rightarrow \mathrm{K}_{2} \mathrm{SO}_{4}(\mathrm{~s}, \mathrm{l})+2 \mathrm{HCl}
$$

Here $s$ and 1 denote solid and liquid species, respectively, while the remaining species are gaseous. These reactions have been reported to be slower than the homogeneous sulfation occurring in the gas-phase, ${ }^{17,36}$ leading to the assumption that the in-flight sulfation of particulate $\mathrm{KCl}$ is insignificant in a furnace where the residence time in suspension is of the order of a few seconds. However, for $\mathrm{KCl}$ condensed on deposits, the available reaction time for sulfation is orders of magnitude longer. Corrosion due to $\mathrm{HCl}$ release close to the metal surface is in discussion, ${ }^{29,37-39}$ but recent results indicate that the sulfation reaction serves to reduce the corrosion propensity. ${ }^{40}$

In addition to its relevance for biomass combustion, the sulfation of alkali chlorides has implications for industrial production of $\mathrm{HCl}_{1}{ }^{34} \mathrm{HCl}$ emissions from municipal solid waste incinerators ${ }^{41,42}$ and kraft recovery boilers, ${ }^{43}$ as well as for corrosion of gas turbine engine components ${ }^{35}$ and cement kilns. ${ }^{44}$ Despite the importance, there are only few reported experiments on sulfation of solid alkali chlorides. Most previous studies investigated the sulfation of $\mathrm{NaCl}(\mathrm{s})$ by $\mathrm{SO}_{2} \cdot{ }^{34,36}$ In more recent work, Matsuda and co-workers ${ }^{45,46}$ compared the sulfation rates of $\mathrm{NaCl}(\mathrm{s}), \mathrm{KCl}(\mathrm{s})$, and $\mathrm{CaCl}_{2}(\mathrm{~s})$. The reported experiments were typically conducted with a fixed bed of alkali chloride, varying temperature, and concentrations of $\mathrm{SO}_{2}, \mathrm{O}_{2}$, and $\mathrm{H}_{2} \mathrm{O}$. While these studies offer data for reaction rates and orders in reactants, results were mostly obtained for $\mathrm{SO}_{2}$ concentrations of $3000 \mathrm{ppm}$ and larger; i.e., considerably above the levels typically found in combustion systems. For this reason, rate coefficients may not extrapolate well to practical conditions.

The objective of the present work is to study the sulfation of condensed $\mathrm{KCl}$ by $\mathrm{SO}_{2}$ in the temperature range $673-1023 \mathrm{~K}$ and lower $\mathrm{SO}_{2}$ concentrations than in previous work.

Received: March 7, 2013

Revised: April 29, 2013

Published: April 30, 2013 
Experiments are conducted in a fixed bed reactor with reactant levels of 500-3000 ppm $\mathrm{SO}_{2}, 1-20 \% \mathrm{O}_{2}$, and $4-15 \% \mathrm{H}_{2} \mathrm{O}$, and the degree of sulfation monitored by measuring the formation of $\mathrm{HCl}$. A rate expression for the sulfation reaction is derived and results are compared to data from literature.

\section{EXPERIMENTAL SECTION}

The experiments were conducted in a fixed bed quartz reactor, ${ }^{51}$ with solid $\mathrm{KCl}$ placed on a porous quartz plate in an isothermal zone. A schematic of the reactor is shown in Figure 1. Reactant gases $\left(\mathrm{SO}_{2}, \mathrm{O}_{2}\right.$,

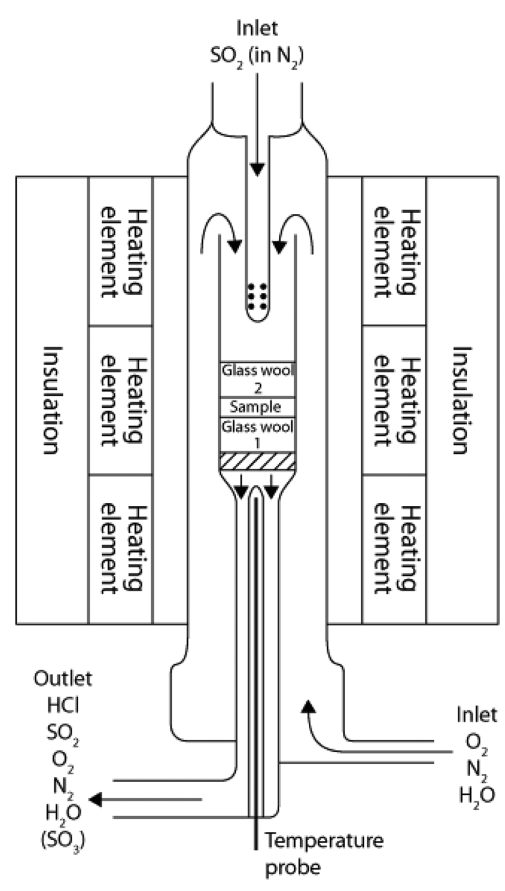

Figure 1. Schematic of the fixed bed reactor.

and $\mathrm{H}_{2} \mathrm{O}$ in $\mathrm{N}_{2}$ ) were introduced separately into the reactor and mixed just above the porous plate. The reactor temperatures were measured under inert conditions with a type $\mathrm{K}$ thermocouple (accuracy $\pm 3 \mathrm{~K}$ ). The temperature in the isothermal zone of the reactor was accurate within $10 \mathrm{~K}$. The product gas was collected in the bottom part of the reactor and led to the online gas analyzers. Heated lines were used to avoid cold-spots where condensation could occur. The concentrations of $\mathrm{HCl}$ and $\mathrm{SO}_{2}$ were measured continuously. The $\mathrm{HCl}$ analyzer (Servomex Servotough 2510) had an accuracy of $\pm 1 \%$ of the measurement range $(0-200$ or $0-1000 \mathrm{ppm}$, depending on conditions). The exit concentration of $\mathrm{SO}_{2}$ was measured with an analyzer accuracy of $\pm 3 \%$, but the possible adsorption of $\mathrm{SO}_{2}$ onto tube surfaces contributes to the uncertainty for this species. In selected experiments, the $\mathrm{KCl}$ conversion to $\mathrm{K}_{2} \mathrm{SO}_{4}$ was quantified from analysis of the solid residue collected from the tests by ICP (inductively coupled plasma) spectroscopy. However, the uncertainty with the ICP analysis was considerable, partly due to difficulties in separating the sample from the quartz wool.

The experiments were conducted with commercial solid potassium chloride (purity 99.5\%), and a mixture of $\mathrm{SO}_{2}, \mathrm{O}_{2}$, and $\mathrm{N}_{2}$ from gas cylinders. Water vapor was added by saturating a nitrogen stream. The $\mathrm{KCl}$ was prepared by grinding and sieving to obtain a size range of 90-125 $\mu \mathrm{m}$. A $1 \mathrm{~g}$ portion of sample material was used for each experiment. The $\mathrm{KCl}$ sample was placed in between two layers of quartz wool to limit loss of solid or molten material.

After placing the $\mathrm{KCl}$ sample inside the quartz reactor, it was exposed to $\mathrm{N}_{2}$ for $30 \mathrm{~min}$ to allow the temperature to reach the desired value. Then the $\mathrm{N}_{2}$ was replaced with a mixture of $\mathrm{O}_{2}, \mathrm{SO}_{2}, \mathrm{H}_{2} \mathrm{O}$, and $\mathrm{N}_{2}$ (total gas flow of $1000 \mathrm{~mL} \mathrm{~min}^{-1} \mathrm{STP}$ ). After $1 \mathrm{~h}$ of sulfation, the reactant gas was replaced by inert. The mass of the water bottle was determined, and the flows were checked to ensure that they did not deviate significantly from the set-point values.

During experiments, the reactor pressure was about 1.05 atm, varying slightly depending on the packing of the fixed bed. In the results discussed in the present work, the progress of reaction was based on the measurement of the exit concentration of $\mathrm{HCl}$ from the reactor. The measured consumption of $\mathrm{SO}_{2}$ corresponded well to the formation of $\mathrm{HCl}$. Reaction rates based on analysis of the solid residue collected from the tests were in reasonable agreement with data obtained from $\mathrm{HCl}$ detection but involved a significantly larger uncertainty.

Residual particles, collected from selected experiments, were sectioned and analyzed by SEM-EDS (scanning electron microscopy and electron dispersive X-rays spectroscopy). Furthermore, the fixed experiments were supplemented with results obtained from simultaneous thermal analysis (STA) with a heating rate of $5 \mathrm{~K} \mathrm{~min}^{-1}$.

\section{NUMERICAL PROCEDURE}

Following the work of Matsuda et al., ${ }^{46}$ the reaction rate was defined as $\mathrm{d} X / \mathrm{d} t$, where $X$ is the fractional conversion of $\mathrm{KCl} . X$ is defined as

$$
X=\frac{m_{0}-m}{m_{0}}
$$

where $m_{0}(\mathrm{~kg})$ is the initial mass of the $\mathrm{KCl}$ particle and $m(\mathrm{~kg})$ is the mass of the remaining unconverted $\mathrm{KCl}$ particle. For each experiment, $\mathrm{d} X / \mathrm{d} t$ was determined from equation (4):

$$
\frac{\mathrm{d} X}{\mathrm{~d} t}=\dot{V}[\mathrm{HCl}] \frac{\mathrm{MW}_{\mathrm{KCl}}}{m_{\mathrm{KCl}}}
$$

Here $\dot{V}\left(\mathrm{~m}^{3} \mathrm{~s}^{-1}\right)$ is the total gas flow, $[\mathrm{HCl}]\left(\mathrm{mol} \mathrm{m}^{-3}\right)$ is the peak concentration of $\mathrm{HCl}, \mathrm{MW}_{\mathrm{KCl}}\left(\mathrm{kg} \mathrm{mol}^{-1}\right)$ is the molecular weight of $\mathrm{KCl}$, and $m_{\mathrm{KCl}}(\mathrm{kg})$ is the initial sample mass of $\mathrm{KCl}$.

In the interpretation of the data, it is assumed that the particle is spherical and converted according to an unreacted shrinking core model under chemical reaction control. The assumption of a shrinking core model is based on the results reported by van Lith et al. ${ }^{39}$ Further support is provided by the SEM-EDS analysis of the residual particles in the present work, as discussed below. Mass transfer limitations in the gas-film or the product layer are neglected, since the particles are small and since the rate is determined at low conversions of $\mathrm{KCl}$.

With the assumption of a shrinking core model, the rate of conversion is given as

$$
\frac{\mathrm{d} X}{\mathrm{~d} t}=k^{\prime}(1-X)^{2 / 3} \mathrm{~F}\left(Y_{\mathrm{SO}_{2}}, Y_{\mathrm{O}_{2}}, Y_{\mathrm{H}_{2} \mathrm{O}}\right)
$$

Here, the rate constant $k^{\prime}\left(\mathrm{s}^{-1}\right)$, in Arrhenius form, describes the temperature dependence and $F$ describes the functional dependence on the reactant mole fractions $\left(Y_{i}\right)$.

Two formulations of the rate expression were used to analyze the experimental results. The first equation is similar to the one used by Matsuda et al.: ${ }^{46}$

$$
\frac{\mathrm{d} X}{\mathrm{~d} t}=k_{\mathrm{A}}(1-X)^{2 / 3}\left(Y_{\mathrm{SO}_{2}}\right)^{1}\left(Y_{\mathrm{O}_{2}}\right)^{m}\left(Y_{\mathrm{H}_{2} \mathrm{O}}\right)^{n}
$$

In the second formulation, we employ a Langmuir-Hinshelwood expression to describe the dependence on the $\mathrm{SO}_{2}$ concentration:

$$
\frac{\mathrm{d} X}{\mathrm{~d} t}=k_{\mathrm{B}}(1-X)^{2 / 3} \frac{Y_{\mathrm{SO}_{2}}}{1+K Y_{\mathrm{SO}_{2}}}\left(Y_{\mathrm{O}_{2}}\right)^{m}\left(Y_{\mathrm{H}_{2} \mathrm{O}}\right)^{n}
$$


Equations 6 and 7 are only valid for the specific particle size $R_{0}$ used in the experiments. To predict the sulfation rate for other particle sizes, we derive a surface area based rate constant $k_{\mathrm{s}}^{\prime}(\mathrm{kg}$ $\mathrm{m}^{-2} \mathrm{~s}^{-1}$ ), which is assumed to be universal for particles of difference size. Substitution of eq 3 for $X$ into eq 5 yields

$$
\frac{\mathrm{d} m}{\mathrm{~d} t}=-k^{\prime} m_{0}\left(\frac{m}{m_{0}}\right)^{2 / 3} F\left(Y_{\mathrm{SO}_{2}}, Y_{\mathrm{O}_{2}}, Y_{\mathrm{H}_{2} \mathrm{O}}\right)
$$

For a spherical particle, the equation above can be converted to

$$
\frac{\mathrm{d} m}{\mathrm{~d} t}=-k^{\prime} \frac{1}{3} R \rho_{\mathrm{KCl}^{1}} 4 \pi r^{2} \mathrm{~F}\left(Y_{\mathrm{SO}_{2}}, Y_{\mathrm{O}_{2}}, Y_{\mathrm{H}_{2} \mathrm{O}}\right)
$$

where $R(\mathrm{~m})$ is the initial radius of the particle, $\rho_{\mathrm{KCl}}\left(\mathrm{kg} \mathrm{m}^{-3}\right)$ is the density of the $\mathrm{KCl}$ particle, and $r(\mathrm{~m})$ is the radius of the remaining unconverted particle. From eq 9, the surface area based rate constant $k_{\mathrm{s}}^{\prime}$ can be obtained:

$$
k_{\mathrm{s}}^{\prime}=k^{\prime} \frac{1}{3} R \rho_{\mathrm{KCl}}
$$

Since eq 10 is assumed valid for all particle sizes, the conversion-based rate constant $k_{1}\left(\mathrm{~s}^{-1}\right)$ for a particle with an initial radius of $R_{1}$ can be calculated as

$$
k_{1}^{\prime}=k^{\prime} \frac{R_{0}}{R_{1}}
$$

In the present study, the diameters of the $\mathrm{KCl}$ particles were in the range $90-125 \mu \mathrm{m}$. By assuming an equal mass distribution (with an interval of $1 \mu \mathrm{m}$ ) of the particles in this size range, we calculate a harmonic mean radius $R_{0}$ of $53.2 \mu \mathrm{m}$.

\section{RESULTS AND DISCUSSION}

Experiments on sulfation of solid $\mathrm{KCl}$ were conducted, varying temperature $(673-1023 \mathrm{~K})$ and reactant concentrations (5003000 ppm $\left.\mathrm{SO}_{2}, 1-20 \% \mathrm{O}_{2}, 4-15 \% \mathrm{H}_{2} \mathrm{O}\right)$. All reported concentrations are volume based and on a wet basis. In the following, the effect of temperature and gas composition on the sulfation rate is investigated. On the basis of these data, a model for the rate of sulfation is established and compared with results from the literature.

Effect of Temperature. For the baseline gas composition

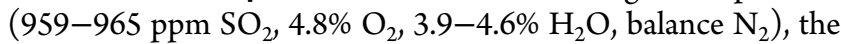
temperature was varied in the range 673-1023 K. Figure 2 shows the measured $\mathrm{HCl}$ profiles for the different temperatures.

At the lowest temperatures, the amount of $\mathrm{HCl}$ generated is comparatively small and the reaction rate derived is more uncertain. Above $900 \mathrm{~K}$, the formation of $\mathrm{HCl}$ increases rapidly with temperature. At $1023 \mathrm{~K}$, a second peak in $\mathrm{HCl}$ is observed after approximately $2500 \mathrm{~s}$ reaction time, indicating a sudden increase in the reaction rate. We attribute this phenomenon to a phase transition from a solid to a melt, likely due to the formation of an eutectic mixture of $\mathrm{KCl}$ and $\mathrm{K}_{2} \mathrm{SO}_{4}$. The melting is supported by the detection of an increased pressure in the reactor, caused by blocking of the pores in the quartz plate by the molten phase.

To confirm that a $\mathrm{KCl}-\mathrm{K}_{2} \mathrm{SO}_{4}$ eutectic was formed during the experiments at $1023 \mathrm{~K}$, the collected residual particles were sectioned and analyzed by SEM-EDS. Typical results are presented in Figure 3, where a mixture of $\mathrm{KCl}-\mathrm{K}_{2} \mathrm{SO}_{4}$ with a lamellar structure is observed. Such a regular lamellar structure is a characteristic microstructure of an eutectic, ${ }^{52,53}$ strongly supporting the presence of a $\mathrm{KCl}-\mathrm{K}_{2} \mathrm{SO}_{4}$ eutectic under the

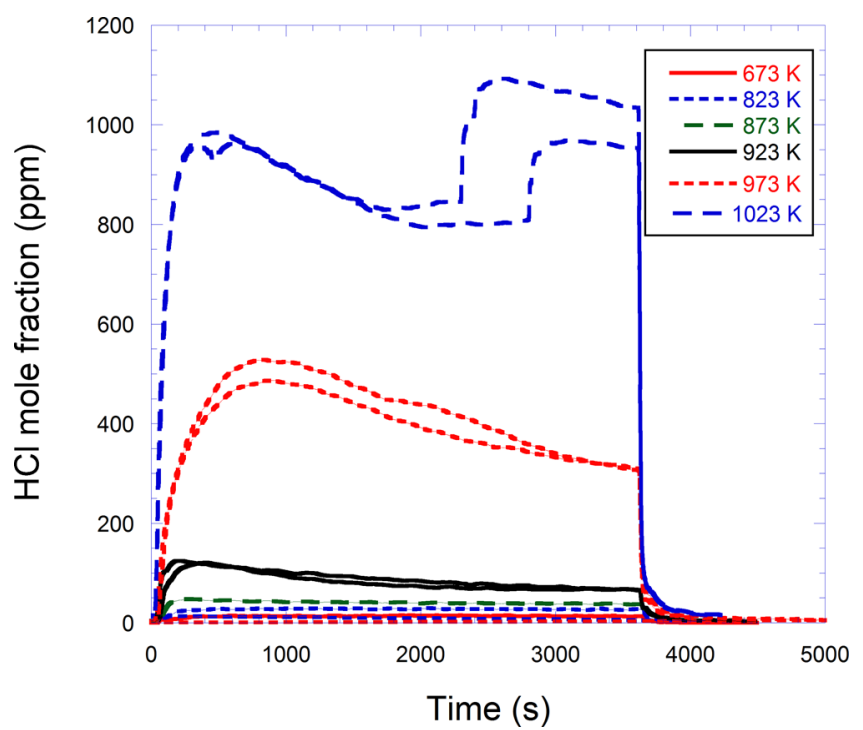

Figure 2. Measured $\mathrm{HCl}$ concentrations as a function of temperature and reaction time. Temperature 673-1023 K; gas composition 959965 ppm $\mathrm{SO}_{2}, 4.8 \% \mathrm{O}_{2}, 3.9-4.6 \% \mathrm{H}_{2} \mathrm{O}$, balance $\mathrm{N}_{2}$.

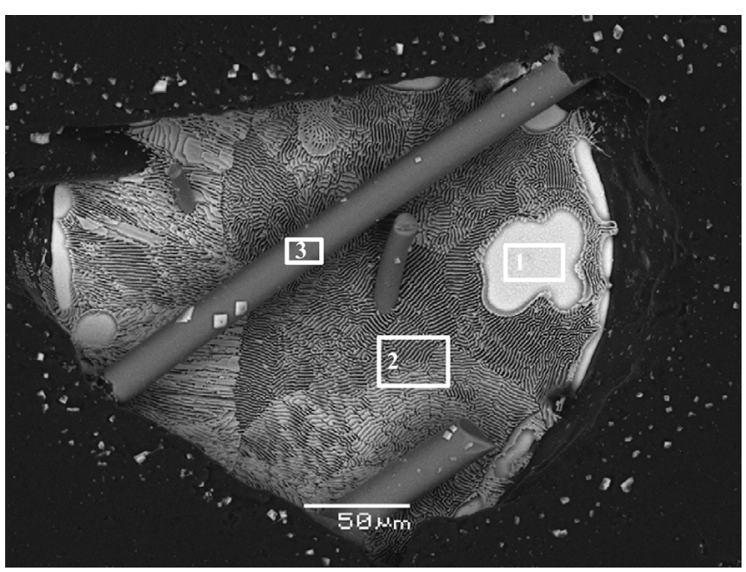

Figure 3. SEM (backscattered electrons, acceleration voltage $15 \mathrm{~kW}$ ) image of the sectioned residual particles collected from the $\mathrm{KCl}$ sulfation experiment at $1023 \mathrm{~K}$, with the selected areas comprised of (1) $\mathrm{KCl}$; (2) a mixture of $\mathrm{KCl}-\mathrm{K}_{2} \mathrm{SO}_{4}$ with a molar ratio of about $1: 2.1 ;$ (3) $\mathrm{SiO}_{2}$ (quartz wool used in the experiment).

given experimental conditions. The formation of a eutectic has been reported earlier by Fielder et al. ${ }^{35}$ in sulfation of $\mathrm{NaCl}(\mathrm{s})$ by $\mathrm{SO}_{3}$ above $900 \mathrm{~K}$. Matsuda et al. ${ }^{46}$ reported eutectic formation in sulfation of $\mathrm{CaCl}_{2}$ but not for $\mathrm{KCl}$ or $\mathrm{NaCl}$. The SEM-EDS analysis also shows that the core of the $\mathrm{KCl}$ particles is unreacted and that the sulfation reaction takes place on the surface. These results supports the assumption of a shrinking core model.

Figure 4 shows an Arrhenius plot of the sulfation reaction. It is evident that a change in reaction mechanism takes place between 823 and $873 \mathrm{~K}$, in agreement with observations in the literature for $\mathrm{KCl}, \mathrm{NaCl}$, and $\mathrm{CaCl}_{2} \cdot{ }^{45,46}$ In the present study, the activation energy for the high-temperature mechanism is determined to be $157 \mathrm{~kJ} \mathrm{~mol}^{-1}$, in good agreement with the values of $137(\mathrm{KCl})$ and $144 \mathrm{~kJ} \mathrm{~mol}^{-1}(\mathrm{NaCl})$ reported by Matsuda and co-workers, ${ }^{45,46}$ but somewhat higher than the $115 \mathrm{~kJ} \mathrm{~mol}^{-1}$ derived for $\mathrm{NaCl}$ by Henriksson and Warnqvist. ${ }^{34}$ Due to the small number of data points in the 623-873 K range and the limited experimental accuracy at low $\mathrm{HCl}$ 


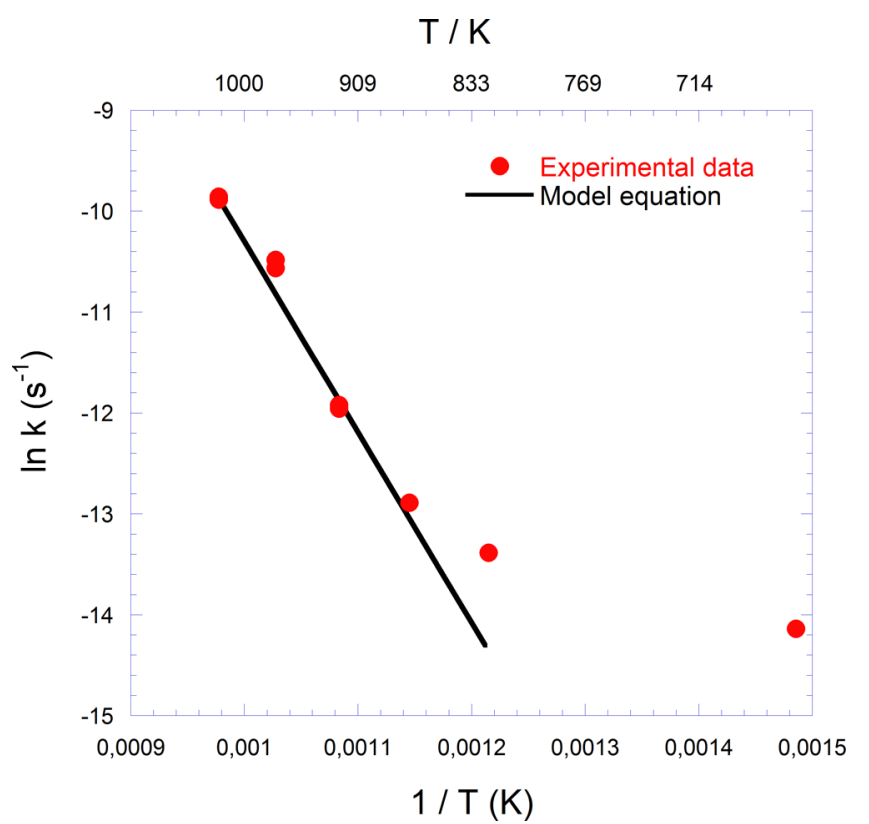

Figure 4. Arrhenius plot for the rate constant of sulfation of $\mathrm{KCl}$ and $\mathrm{NaCl}$ with $\mathrm{SO}_{2}$. Temperature 673-1023 K; gas composition 959-965 ppm $\mathrm{SO}_{2}, 4.8 \% \mathrm{O}_{2}, 3.9-4.6 \% \mathrm{H}_{2} \mathrm{O}$, balance $\mathrm{N}_{2}$.

concentrations, we cannot reliably determine the activation energy for the low-temperature mechanism, but our results are consistent with values of $3.4-23 \mathrm{~kJ} \mathrm{~mol}^{-1}$ reported for $\mathrm{KCl}$ and $\mathrm{NaCl}{ }^{36,45,46}$

The reason for the observed change in mechanism is still unresolved. Results from simultaneous thermal analysis (STA) for $\mathrm{KCl}$ indicated a phase transition of $\mathrm{KCl}$ around $1058 \mathrm{~K}$, but no change in the crystal form of $\mathrm{KCl}$ was observed in the temperature range $823-923 \mathrm{~K}$. Potassium sulfate exhibited a reversible change in crystal form at around $860 \mathrm{~K}$, in agreement with literature reports, ${ }^{47,48}$ but the enthalpy of transformation is only about $5.8 \mathrm{~kJ} \mathrm{~mol}^{-1} 48$ and cannot in itself explain the change in activation energy of the sulfation reaction.

A plausible explanation to the observed change of mechanism is that the sulfation at low temperatures involves a condensed-phase intermediate, perhaps a potassium sulfite, with reduced thermal stability at temperatures above $900 \mathrm{~K}$. Another possibility is that the low-temperature reaction involves $\mathrm{SO}_{3}$, rather than $\mathrm{SO}_{2}$, as reactant. The reaction between $\mathrm{KCl}(\mathrm{s}, \mathrm{l})$ and $\mathrm{SO}_{3}$ has been shown to proceed essentially without an activation energy. ${ }^{35}$ Even though quartz is not very effective as a catalyst for $\mathrm{SO}_{2}$ oxidation, ${ }^{49}$ its presence (wool bed, reactor surface) may facilitate formation of $\mathrm{SO}_{3}$ in quantities sufficient to explain the observed (small) conversion. A mechanism that involves surface oxidation of $\mathrm{SO}_{2}$ would also help to explain the large scatter in reported sulfation rates in the 600-900 $\mathrm{K}$ range (see below).

It should be noted that the sulfation products at low temperatures (e.g., $673 \mathrm{~K}$ ) may be dominated by potassium pyrosulfate $\left(\mathrm{K}_{2} \mathrm{~S}_{2} \mathrm{O}_{7}\right)$, which is thermodynamically favored compared to $\mathrm{K}_{2} \mathrm{SO}_{4}$ under these conditions. ${ }^{50}$ For both $\mathrm{SO}_{2}$ and $\mathrm{SO}_{3}$ as reactants, the formation of $\mathrm{K}_{2} \mathrm{~S}_{2} \mathrm{O}_{7}$ is exothermic. When the temperature is increased to a range of 823-873 K, decomposition of $\mathrm{K}_{2} \mathrm{~S}_{2} \mathrm{O}_{7}$ to $\mathrm{SO}_{3}+\mathrm{K}_{2} \mathrm{SO}_{4}$ ( $\alpha$ or $\beta$ phase) becomes important. This reaction is endothermic, with calculated reaction enthalpies of $65-75 \mathrm{~kJ} \mathrm{~mol}^{-1}$. 0
Effect of Reactant Concentrations. A range of experiments were conducted at $923 \mathrm{~K}$ to determine the dependence of the sulfation rate on the concentrations of $\mathrm{SO}_{2}, \mathrm{O}_{2}$, and $\mathrm{H}_{2} \mathrm{O}$. Figure 5 shows results for variation of the $\mathrm{SO}_{2}$

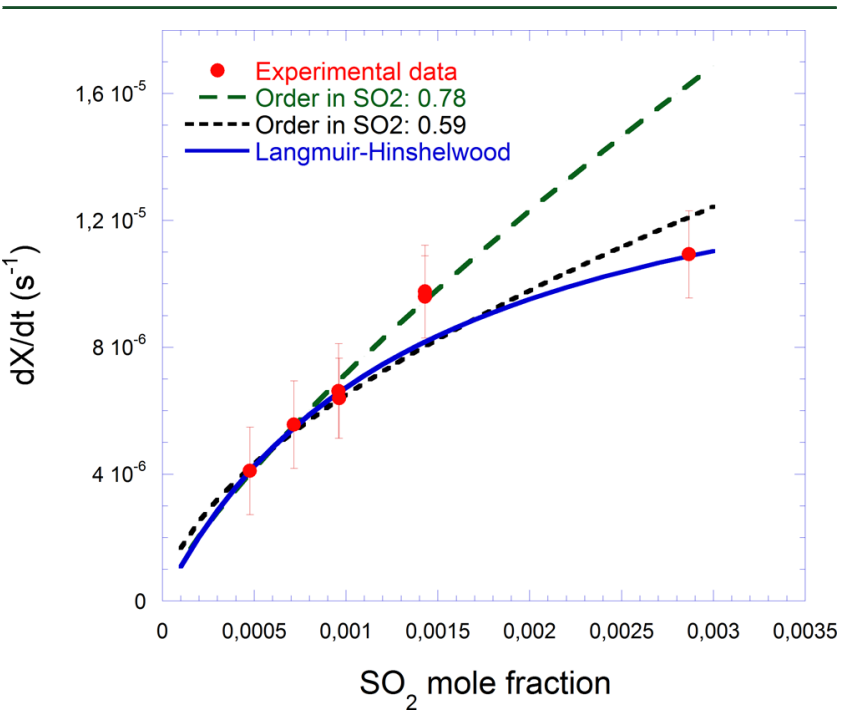

Figure 5. Comparison between the measured and calculated value of $\mathrm{d} X / \mathrm{d} t$ as a function of $\mathrm{SO}_{2}$ concentration. Temperature $923 \mathrm{~K}$; gas composition 500-3000 $\mathrm{ppm} \mathrm{SO}_{2}, 4.8 \% \mathrm{O}_{2}, 4.0-4.6 \% \mathrm{H}_{2} \mathrm{O}$, balance $\mathrm{N}_{2}$.

concentration, maintaining the concentrations of $\mathrm{O}_{2}$ and $\mathrm{H}_{2} \mathrm{O}$ at constant levels. A regression for the range 500-1500 ppm $\mathrm{SO}_{2}$ is consistent with a $\left(\mathrm{Y}_{\mathrm{SO}_{2}}\right)^{0.78}$ dependence (shown as the long-dashed line). As the $\mathrm{SO}_{2}$ concentration is increased further $(3000 \mathrm{ppm})$, the reaction order in $\mathrm{SO}_{2}$ appears to decrease, possibly due to a saturation in $\mathrm{SO}_{2}$ when adsorbing on the surface. Over the range 500-3000 ppm, the best fit is obtained with $\left(\mathrm{Y}_{\mathrm{SO}_{2}}\right)^{0.59}$ (short-dashed line). These values can be compared with a reaction order of 0.5 , obtained for the range 3000-13000 ppm $\mathrm{SO}_{2}$ by Matsuda et al. ${ }^{46}$ An alternative to a power fit is the Langmuir-Hinshelwood type expression (eq 7) of the type $Y_{\mathrm{SO}_{2}} /\left(1+K Y_{\mathrm{SO}_{2}}\right)$ (shown as a solid line for $K=$ $708)$, which may provide a more accurate extrapolation to higher concentrations of $\mathrm{SO}_{2}$.

Figure 6 shows results for variation of $\mathrm{O}_{2}$. These data, obtained over a wide range of $\mathrm{O}_{2}$ concentrations $(1-20 \%)$, are consistent with a reaction order of 0.37 , in good agreement with the value of 0.4 , obtained for the range $2.5-15 \% \mathrm{O}_{2}$ by Matsuda et al. ${ }^{46}$ The water vapor level was varied between 4.3 and $15 \%$ (Figure 7). The water concentration was more difficult to control and to quantify than the other reactant concentrations, but our results show only little sensitivity of the sulfation rate toward $\mathrm{H}_{2} \mathrm{O}$ in the investigated range. A best fit to the data yields a reaction order in $\mathrm{H}_{2} \mathrm{O}$ of 0.15 , but within the uncertainty of the data, the sulfation rate can be assumed independent of $\left[\mathrm{H}_{2} \mathrm{O}\right]$. The results obtained by Matsuda et al. ${ }^{46}$ indicate that above $923 \mathrm{~K}$ the water vapor level (5-20\%) has a larger impact on the sulfation rate, but this cannot be verified from the present work.

Rate Expression for $\mathrm{KCl}$ Sulfation. On the basis of the experimental data, we have determined the sulfation rate as a function of temperature $(873-1023 \mathrm{~K})$ and reactant concentrations as follows. For $\mathrm{SO}_{2}$ concentrations of 500$1500 \mathrm{ppm}$, the eq 6 format works well and we get 


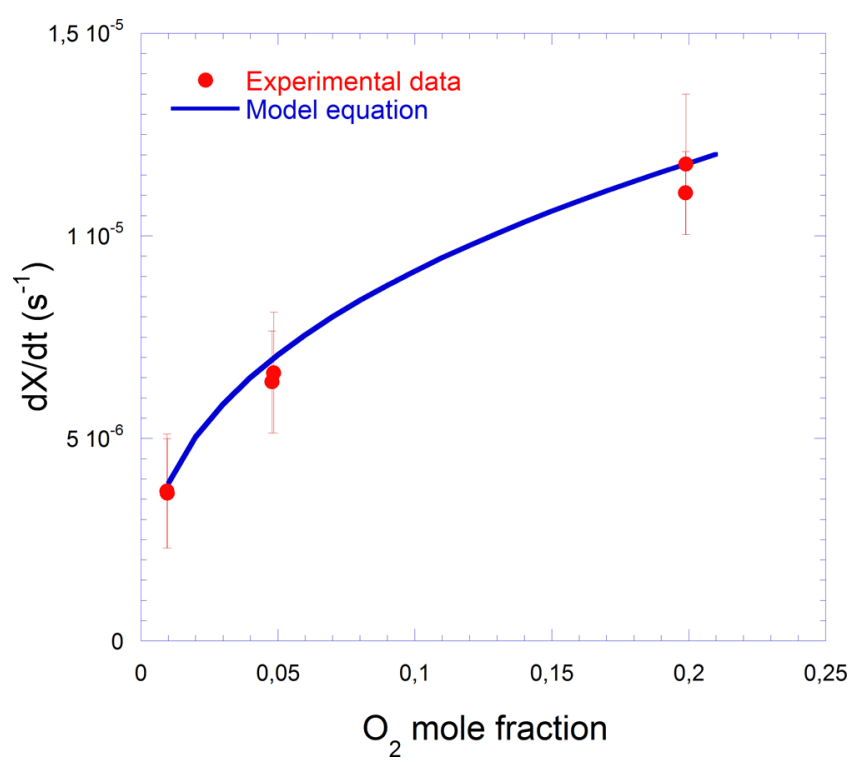

Figure 6. Comparison between the measured and calculated value of $\mathrm{d} X / \mathrm{d} t$ as a function of $\mathrm{O}_{2}$ concentration. Temperature $923 \mathrm{~K}$; gas composition $959-968 \mathrm{ppm} \mathrm{SO}_{2}, 1.0-19.9 \% \mathrm{O}_{2}, 3.8-4.6 \% \mathrm{H}_{2} \mathrm{O}$, balance $\mathrm{N}_{2}$.

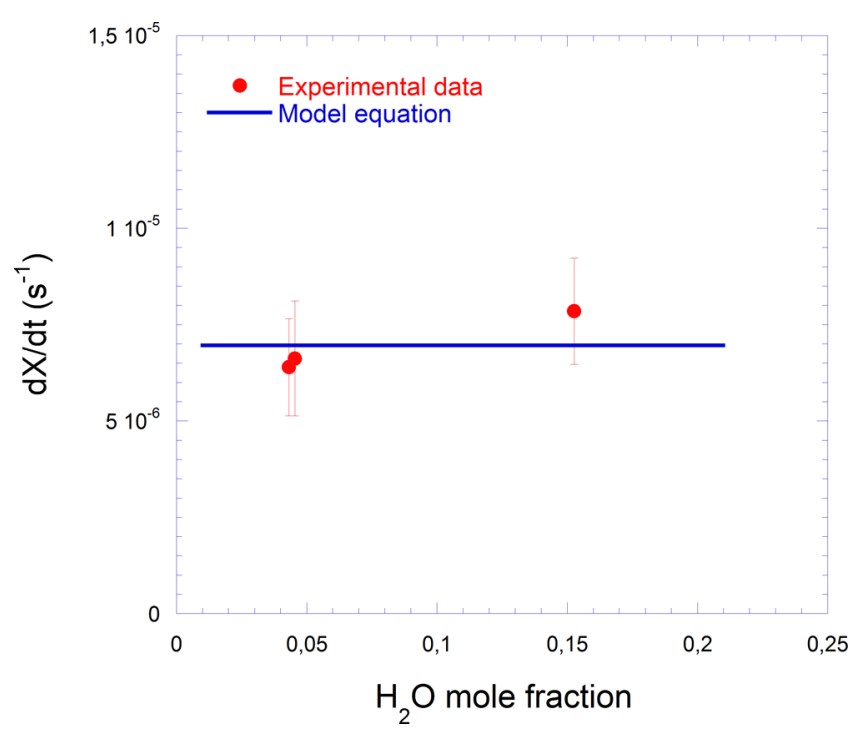

Figure 7. Comparison between the measured and calculated value of $\mathrm{d} X / \mathrm{d} t$ as a function of $\mathrm{H}_{2} \mathrm{O}$ concentration. Temperature $923 \mathrm{~K}$; gas composition 947-962 $\mathrm{ppm} \mathrm{SO}_{2}, 4.8 \% \mathrm{O}_{2}, 4.3-15.3 \% \mathrm{H}_{2} \mathrm{O}$, balance $\mathrm{N}_{2}$.

$$
\begin{aligned}
\frac{\mathrm{d} X}{\mathrm{~d} t}= & 3.7 \times 10^{6} \exp (-18900 / T)(1-X)^{2 / 3}\left(Y_{\mathrm{SO}_{2}}\right)^{0.78} \\
& \left(Y_{\mathrm{O}_{2}}\right)^{0.37}
\end{aligned}
$$

For a wider range of $\mathrm{SO}_{2}$ concentrations, we recommend the eq 7 format with the following parameters:

$$
\begin{aligned}
\frac{\mathrm{d} X}{\mathrm{~d} t}= & 2.7 \times 10^{7} \exp (-18900 / T)(1-X)^{2 / 3} \frac{Y_{\mathrm{SO}_{2}}}{1+708 Y_{\mathrm{SO}_{2}}} \\
& \left(Y_{\mathrm{O}_{2}}\right)^{0.37}
\end{aligned}
$$

The Arrhenius plot in Figure 8 compares the present results with data from the work of Boonsongsup et al. ${ }^{36}$ for $\mathrm{NaCl}$ and

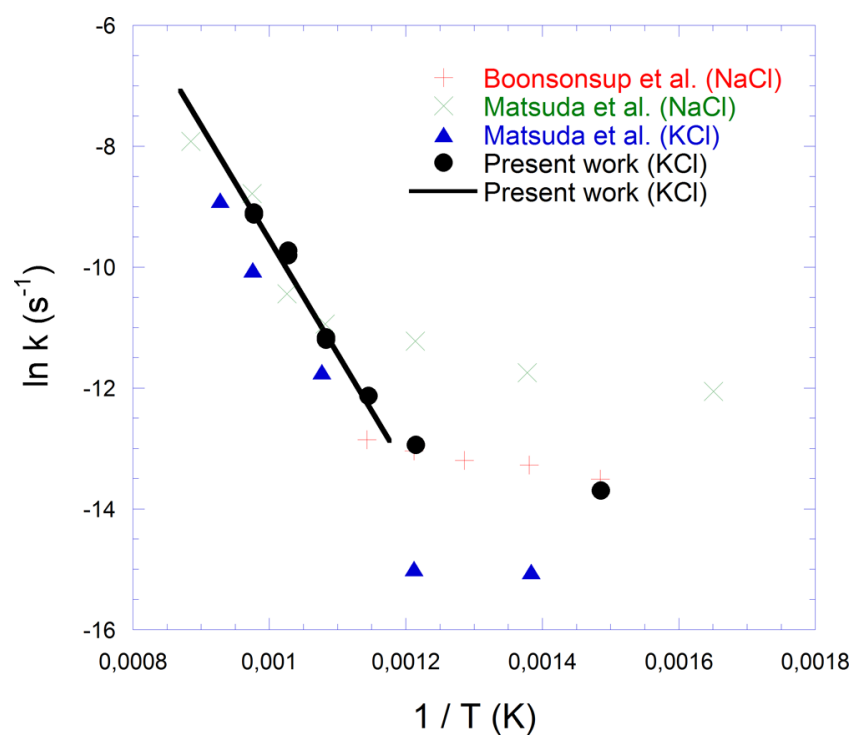

Figure 8. Arrhenius plot for the rate constant of sulfation of $\mathrm{KCl}$ and $\mathrm{NaCl}$ with $\mathrm{SO}_{2}$. Nominal conditions for the comparison: $\mathrm{SO}_{2} 9000$ ppm; $\mathrm{O}_{2} 5.0 \% ; \mathrm{H}_{2} \mathrm{O} 10 \% ; \mathrm{N}_{2}$ balance. Literature data is from Boonsongsup et al. ${ }^{36}$ for $\mathrm{NaCl}$ and Matsuda et al. ${ }^{46}$ for $\mathrm{NaCl}$ and $\mathrm{KCl}$. The present data for $\mathrm{KCl}$ were obtained at conditions with 959-965 ppm $\mathrm{SO}_{2}, 4.8 \% \mathrm{O}_{2}$, and $3.9-4.6 \% \mathrm{H}_{2} \mathrm{O}$. To extrapolate to the conditions of the figure, $\mathrm{SO}_{2}$ was corrected according to the Langmuir-Hinshelwood expression (high temperature) and to $\left(P_{\mathrm{SO}_{2}}\right)^{0.2}$ (low temperature ${ }^{46}$ ), respectively, while no corrections were made for $\mathrm{O}_{2}$ and $\mathrm{H}_{2} \mathrm{O}$.

Matsuda et al. $^{46}$ for $\mathrm{NaCl}$ and $\mathrm{KCl}$. The comparison is complicated by the fact that the measurements were conducted in different $\mathrm{SO}_{2}$ concentration ranges. The data shown in the figure by Boonsongsup et al. and by Matsuda et al. were obtained at $9000 \mathrm{ppm} \mathrm{SO}$, while in the present work the $\mathrm{SO}_{2}$ range was 500-3000 ppm. We extrapolate our results to the higher $\mathrm{SO}_{2}$ level using the Langmuir-Hinshelwood formulation (eq 13) for the high temperature range (873-1023 K). The two data points obtained at the lowest temperatures were corrected using the $\left(\mathrm{P}_{\mathrm{SO}_{2}}\right)^{0.2}$ dependence reported by Matsuda et $\mathrm{al}^{46}$

The data for the sulfation rate of $\mathrm{KCl}$ and $\mathrm{NaCl}$ obtained by Matsuda et al. ${ }^{46}$ above $873 \mathrm{~K}$ are in good agreement with the results of the present work. Our rate constant for $\mathrm{KCl}$ is slightly higher than that reported by Matsuda et al., perhaps because their value is derived for longer reaction times, where product layer diffusion may have affected the sulfation rate. For the low temperature regime, the scatter in the data is significantly larger. Our results are in good agreement with those reported by Boonsongsup et al. and in between data reported by Matsuda et al. for $\mathrm{KCl}$ and $\mathrm{NaCl}$, respectively.

Extrapolation to Higher Temperatures. In order to evaluate how well the model extrapolates to higher temperatures, predictions were compared to data reported by Iisa et al. ${ }^{17}$ They studied sulfation of $\mathrm{KCl}$ particles $(65-125 \mu \mathrm{m})$ at temperatures of $1173-1373 \mathrm{~K}$ in an entrained flow reactor. At these temperatures, a significant fraction of the $\mathrm{KCl}$ evaporates to the gas phase, and three mechanisms of sulfation may be active:

(A) Sulfation of particulate $\mathrm{KCl}$ by reaction with $\mathrm{SO}_{2}$

(B) Sulfation of particulate $\mathrm{KCl}$ by reaction with $\mathrm{SO}_{3}$

(C) Sulfation of gaseous $\mathrm{KCl}$ by reaction with $\mathrm{SO}_{3}$ 
Part of the inlet $\mathrm{SO}_{2}$ may be oxidized homogeneously to $\mathrm{SO}_{3}$, and the presence of $\mathrm{SO}_{3}$ increases the sulfation rate of both particulate $\mathrm{KCl}^{35}$ (mechanism $\mathrm{B}$ ) and gaseous $\mathrm{KCl}^{17,19-22}$ (mechanism C) considerably. Iisa et al. analyzed both the coarse particles collected in the cyclone and the fine particles captured in the filter; from these data they determined the degree of sulfation of both particulate and gaseous $\mathrm{KCl}$.

The results reported by lisa et al. indicate an accelerated sulfation rate of the particulate $\mathrm{KCl}$ at longer residence times in the reactor. We attribute this mostly to interference from mechanisms B and C. Potassium sulfate, formed in the gasphase (C), may condense on the coarse $\mathrm{KCl}$ particles, and also reaction of $\mathrm{KCl}(\mathrm{s})$ with $\mathrm{SO}_{3}$ (B) may have contributed to the observed degree of sulfation. The $\mathrm{B}$ and $\mathrm{C}$ sulfation mechanisms are both controlled by the rate of $\mathrm{SO}_{3}$ formation in the gas-phase. If they were important for the observed sulfation degree of solid $\mathrm{KCl}$ particles, the homogeneous and heterogeneous sulfation rates should be similar. Indeed, this is in agreement with the observations of Iisa et al. for longer reactor residence times $(>1 \mathrm{~s})$.

Iisa et al. ${ }^{17}$ reported the sulfation degree of particulate $\mathrm{KCl}$ as a function of temperature and reactor residence time. Figure 9

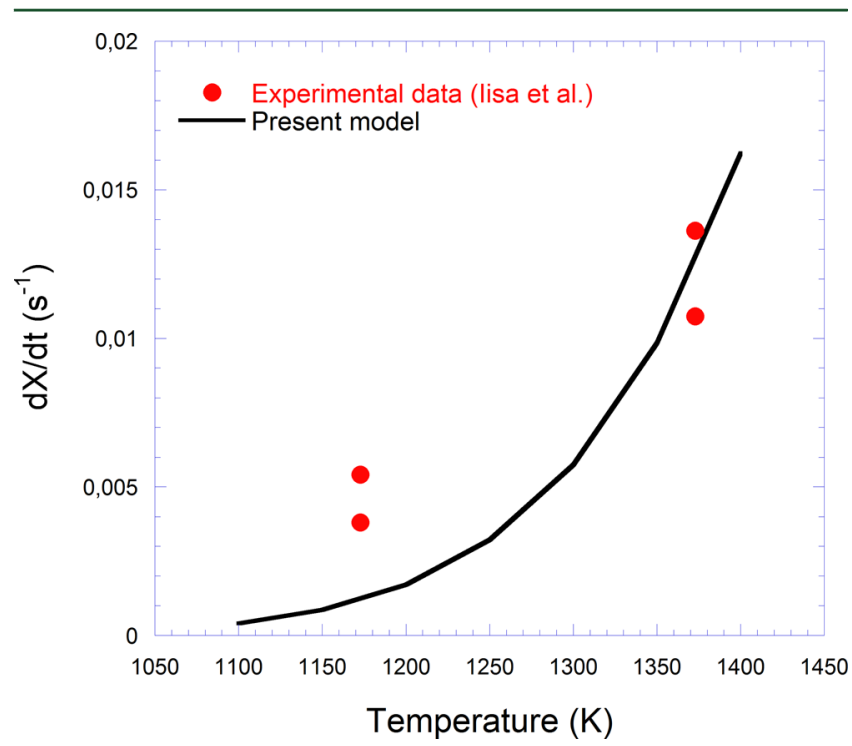

Figure 9. Comparison between measured and calculated values of $\mathrm{d} X /$ $\mathrm{d} t$ as a function of temperature. The experimental data are drawn from the entrained flow reactor work of Iisa et al. ${ }^{17}$ while the calculated values are obtained from eq 13 . Temperatures $1173 \mathrm{~K}$ (residence time $1.0 \mathrm{~s}$ ) and $1373 \mathrm{~K}$ (residence time $0.6 \mathrm{~s}$ ); gas composition $2 \% \mathrm{SO}_{2}, 5 \%$ $\mathrm{O}_{2}, 10 \% \mathrm{H}_{2} \mathrm{O} ; \mathrm{N}_{2}$ balance.

compares $\mathrm{d} X / \mathrm{d} t$ values derived from these data with predictions using eq 13 . Unfortunately, data for short residence times were only reported for a temperature of $1373 \mathrm{~K}(0.6 \mathrm{~s})$. The data shown for $1173 \mathrm{~K}$ were obtained for a residence time of $1.0 \mathrm{~s}$, and they are more prone to be influenced by mechanisms $\mathrm{B}$ and $\mathrm{C}$, since $\mathrm{SO}_{3}$ has had more time to form. Considering the uncertainty, the level of agreement between the entrained flow reactor data and the model is satisfactory.

In-Flight Sulfation of Particulate $\mathrm{KCl}$. To assess the extent of in-flight sulfation of particulate $\mathrm{KCl}$, the conversion has been calculated for different particle sizes and temperatures. The calculations were based on eq 13, correcting for the effect of particle radius following eq 11 :

$$
\begin{aligned}
\frac{\mathrm{d} X}{\mathrm{~d} t}= & 2.7 \times 10^{7} \exp (-18900 / T)(1-X)^{2 / 3} \frac{Y_{\mathrm{SO}_{2}}}{1+708 Y_{\mathrm{SO}_{2}}} \\
& \left(Y_{\mathrm{O}_{2}}\right)^{0.37} \frac{R_{0}}{R_{1}}
\end{aligned}
$$

Here, $R_{0}$ is $53.2 \mu \mathrm{m}$; the harmonic mean diameter of the particle size range $(90-125 \mu \mathrm{m})$ used in deriving the kinetic parameters.

The results are shown in Figure 10, which are obtained based on a gas mixture with $1000 \mathrm{ppm} \mathrm{SO}_{2}$ and $5 \% \mathrm{O}_{2}$, and a

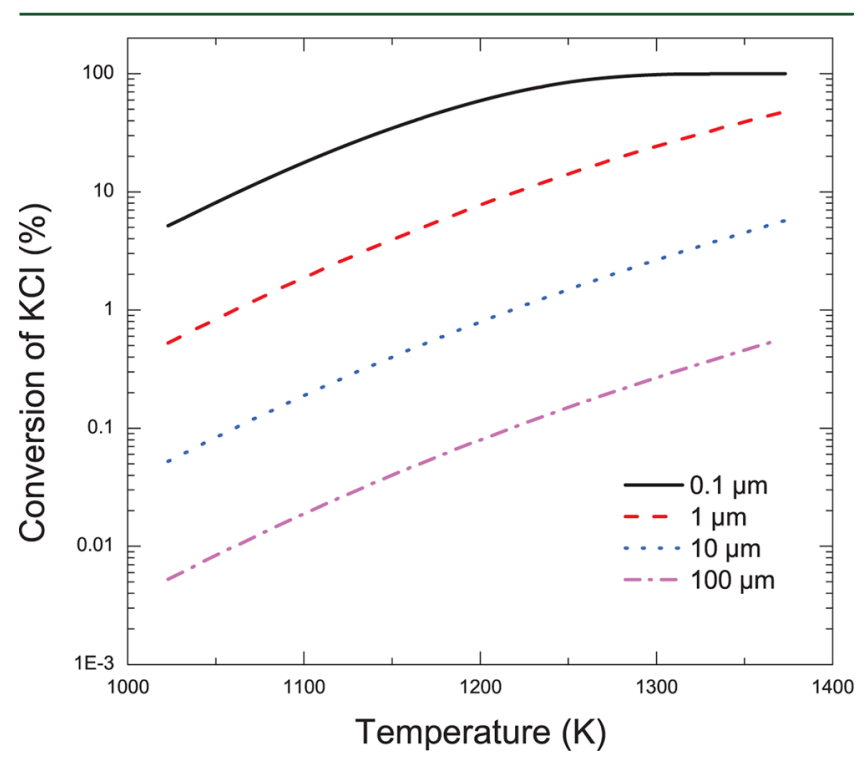

Figure 10. Calculated conversion (\%) of $\mathrm{KCl}$ particles under different size and temperature conditions by using eq 14 . The calculations are based on $1000 \mathrm{ppm} \mathrm{SO}_{2}, 5 \% \mathrm{O}_{2}$, and a residence time of $1 \mathrm{~s}$.

residence time of $1 \mathrm{~s}$. It can be seen that only for very small $\mathrm{KCl}$ particles $(0.1-1 \mu \mathrm{m})$, a considerable in-flight conversion (in the range $1-100 \%$ ) can be achieved. However, $\mathrm{KCl}$ aerosols, from homogeneous nucleation (at low particle loadings) or from heterogeneous condensation on $\mathrm{K}_{2} \mathrm{SO}_{4}$ nuclei, are unlikely to form at temperatures above $1100 \mathrm{~K}^{22}$ At temperatures below this value, the conversion of the submicrometer particles is limited to below $20 \%$. For particles with diameters larger than $10 \mu \mathrm{m}$, the conversion is only a few percent even at very high temperatures. These results indicate that in-flight sulfation of particulate $\mathrm{KCl}$ in combustion systems is limited, in agreement with earlier findings. ${ }^{17,36}$

\section{CONCLUSIONS}

The sulfation of condensed $\mathrm{KCl}$ by $\mathrm{SO}_{2}$ was studied in the temperature range $673-1023 \mathrm{~K}$ and with reactant concentrations of 500-3000 ppm $\mathrm{SO}_{2}, 1-20 \% \mathrm{O}_{2}$, and 4-15\% $\mathrm{H}_{2} \mathrm{O}$. Experiments were conducted in a fixed bed reactor, and the degree of sulfation monitored by measuring the formation of $\mathrm{HCl}$ and analysis of the solid residue. On the basis of the experimental results, the rate of the sulfation reaction can be described by the expression $\mathrm{d} X / \mathrm{d} t=2.7 \times 10^{7} \exp (-18900 /$ $T)(1-X)^{2 / 3}\left[Y_{\mathrm{SO}_{2}} /\left(1+708 Y_{\mathrm{SO}_{2}}\right)\right]\left(Y_{\mathrm{O}_{2}}\right)^{0.37}$ for particles in the range $90-125 \mu \mathrm{m}$. The model compares well with literature data for sulfation of $\mathrm{KCl}$ and $\mathrm{NaCl}$, and the results indicate that it may be applied even at higher $\mathrm{SO}_{2}$ concentrations and temperatures than those of the present study. Simulations of 
the condensed phase sulfation of $\mathrm{KCl}$ particles with different size indicate that a considerable in-flight sulfation may be achieved only for $\mathrm{KCl}$ particles below $1 \mu \mathrm{m}$ in combustion systems.

\section{AUTHOR INFORMATION}

\section{Corresponding Author}

*E-mail: pgl@kt.dtu.dk.

\section{Notes}

The authors declare no competing financial interest.

\section{ACKNOWLEDGMENTS}

Funding from EU Contract No. 23946 "Demonstration of a 16 MW High Energy Efficient Corn Stover Biomass Power Plant”, from Energinet.dk as part of the Eranet Bioenergy program, from the Danish National Advanced Technology Foundation, and from FLSmidth A/S is gratefully acknowledged.

\section{REFERENCES}

(1) Olsson, J. G.; Jaglid, U.; Pettersson, J. B. C.; Hald, P. Energy Fuels 1997, 11, 779-784.

(2) Björkman, E.; Strömberg, B. Energy Fuels 1997, 11, 1026-1032.

(3) Knudsen, J. N.; Jensen, P. A.; Lin, W.; Frandsen, F. J.; DamJohansen, K. Energy Fuels 2004, 18, 810-819.

(4) Knudsen, J. N.; Jensen, P. A.; Dam-Johansen, K. Energy Fuels 2004, 18, 1385-1399.

(5) Knudsen, J. N.; Jensen, P. A.; Lin, W.; Dam-Johansen, K. Energy Fuels 2005, 19, 606-617.

(6) Keown, D. M.; Favas, G.; Hayashi, J.; Li, C.-Z. Biores. Technol. 2005, 96, 1570-1577.

(7) Okuno, T.; Sonoyama, N.; Hayashi, J.-I.; Li, C.-Z.; Sathe, C.; Chiba, T. Energy Fuels 2005, 19, 2164-2171.

(8) van Lith, S. C.; Ramirez, V. A.; Jensen, P. A.; Frandsen, F. J.; Glarborg, P. Energy Fuels 2006, 20, 964-978.

(9) van Lith, S. C.; Jensen, P. A.; Frandsen, F. J.; Glarborg, P. Energy Fuels 2008, 22, 1598-1609.

(10) Tillman, D. A.; Duong, D.; Miller, B. Energy Fuels 2009, 23, 3379-3391.

(11) Johansen, J. M.; Jakobsen, J. G.; Frandsen, F. J.; Glarborg, P. Energy Fuels 2011, 25, 4961-4971.

(12) Zhang, Z.-H.; Song, Q.; Yao, Q.; Yang, R.-M. Energy Fuels 2012, 26, 1892-1899.

(13) Boström, D.; Skoglund, N.; Grimm, A.; Boman, C.; Öhman, M.; Broström, M.; Backman, R. Energy Fuels 2012, 26, 85-93.

(14) Zevenhoven, M.; Yrjas, P.; Skrifvars, B.-J.; Hupa, M. Energy Fuels 2012, 26, 6366-6386.

(15) Jenkins, B. M.; Baxter, L. L.; Miles, T. R., Jr.; Miles, T. R. Fuel Process. Technol. 1998, 54, 17-46.

(16) Coda, B.; Aho, M.; Berger, R.; Hein, K. R. G. Energy Fuels 2001, $15,680-690$.

(17) Iisa, K.; Lu, Y.; Salmenoja, K. Energy Fuels 1999, 13, 1184-1190.

(18) Jimenez, S.; Ballester, J. Combust. Flame 2005, 140, 346-358.

(19) Glarborg, P.; Marshall, P. Combust. Flame 2005, 141, 22-39.

(20) Jimenez, S.; Ballester, J. Fuel 2007, 86, 486-493.

(21) Hindiyarti, L.; Frandsen, F. J.; Livbjerg, H.; Glarborg, P.; Marshall, P. Fuel 2008, 87, 1591-1600.

(22) Li, B.; Sun, Z.; Li, Z.; Alden, M.; Jakobsen, J. G.; Hansen, S.; Glarborg, P. Combust. Flame 2013, 160, 959-969.

(23) Christensen, K. A.; Stenholm, M.; Livbjerg, H. Aerosol Sci. Technol. 1998, 29, 421-444.

(24) Christensen, K. A.; Livbjerg, H. Aerosol Sci. Technol. 2000, 33, $470-489$.

(25) Jensen, J. R.; Nielsen, L. B.; Schultz-Moller, C.; Wedel, S.; Livbjerg, H. Aerosol Sci. Technol. 2000, 33, 490-509.

(26) Nielsen, H. P.; Baxter, L. L.; Sclippa, G.; Morey, C.; Frandsen, F. J.; Dam-Johansen, K. Fuel 2000, 79, 131-139.
(27) Zeuthen, J. H.; Jensen, P. A.; Jensen, J. R.; Livbjerg, H. Energy Fuels 2007, 21, 699-709.

(28) Frandsen, F. J. Fuel 2005, 84, 1277-1294.

(29) Karlsson, S.; Pettersson, J.; Johansson, L. G.; Svensson, J. E. Oxid. Metals 2012, 78, 83-102.

(30) Zheng, Y. J.; Jensen, A. D.; Johnsson, J. E. Appl. Cat. B Env. 2005, 60, 253-264.

(31) Larsson, A. C.; Einvall, J.; Andersson, A.; Sanati, M. Energy Fuels 2006, 20, 1398-1405.

(32) Kling, A.; Andersson, C.; Myringer, A.; Eskilsson, D.; Jaras, S. G. Appl. Cat. B Environ. 2007, 69, 240-251.

(33) Zheng, Y. J.; Jensen, A. D.; Johnsson, J. E. Appl. Cat. B Environ. 2008, 83, 186-194.

(34) Henriksson, M.; Warnqvist, B. Ind. Chem. Process Des. Dev. 1979, $18,249-254$.

(35) Fielder, W. L.; Stearns, C. A.; Kohl, F.J. J. Electrochem. Soc. 1984, 131, 2414-2417.

(36) Boonsongsup, L.; Iisa, K.; Frederick, W. J., Jr. Ind. Eng. Chem. Res. 1997, 36, 4212-4216.

(37) Nielsen, H. P.; Frandsen, F. J.; Dam-Johansen, K. Energy Fuels 1999, 13, 1114-1121.

(38) Nielsen, H. P.; Frandsen, F. J.; Dam-Johansen, K.; Baxter, L. L. Prog. Energy Combust. Sci. 2000, 26, 283-298.

(39) van Lith, S. C.; Frandsen, F. J.; Montgomery, M.; Vilhlemsen, T.; Jensen, S. A. Energy Fuels 2009, 23, 3457-3468.

(40) Paneru, M.; Maier, J.; Stein-Brzozowska, G.; Scheffknecht, G. Corrosion mechanism of alloy 310 austenetic steel beneath $\mathrm{NaCl}$ deposit under varying $\mathrm{SO} 2$ concentration in oxy-fuel combustion atmosphere. Proceedings of the Impacts of Fuel Quality on Power Generation and the Environment; Puchberg am Schneeberg, Austria, 2012.

(41) Uchida, S.; Kamo, H.; Kubota, H.; Kanaya, K. Ind. Chem. Process Design Dev. 1983, 22, 144-149.

(42) Uchida, S.; Kamo, H.; Kubota, H. Ind. Eng. Chem. Res. 1988, 27, $2188-2190$

(43) Warnqvist, R.; Norrström, H. Tappi 1976, 59, 89.

(44) Saint-Jean, S. J.; Jøns, E.; Lundgaard, N.; Hansen, S. Cem. Concr. Res. 2005, 35, 431-437.

(45) Ozawa, S.; Ito, K.; Matsuda, H. Kagaku Kogaku Ronbunshu 2002, 28, 396-403.

(46) Matsuda, H.; Ozawaa, S.; Narusea, K.; Itoa, K.; Kojimab, Y.; Yanasec, T. Chem. Eng. Sci. 2005, 60, 545-552.

(47) Arnold, H.; Kurtz, W.; Richterzinnius, A.; Bethke, J.; Heger, G. Aacta Crystallogr. Sec. B Struct. Sci. 1981, 37, 1643-1651.

(48) Bin Anooz, S.; Bertram, R.; Klimm, D. Solid State Commun. 2007, 141, 497-501.

(49) Jørgensen, T. L.; Livbjerg, H.; Glarborg, P. Chem. Eng. Sci. 2007, 62, 4496-4499.

(50) Lindberg, D.; Backman, R.; Chartrand, P. J. Chem. Thermodyn. 2006, 38, 1568-1583.

(51) Jensen, A.; Johnsson, J. E.; Dam-Johansen, K. AIChE J. 1997, 43, 3070-3084.

(52) Asta, M.; Beckermann, C.; Karma, A.; Kurz, W.; Napolitano, R.; Plapp, M.; Purdy, G.; Rappaz, M.; Trivedi, R. Acta Mater. 2009, 57, 941-971.

(53) Elliott, R. Eutectic solidification processing: crystalline and glassy alloys, Butterworths, 1983. 